\title{
Peningkatan Kemampuan Motorik Kasar Melalui Permainan Sirkuit Terowongan Geometri pada Anak Kelompok A di TK Kartika Bojonegoro
}

\author{
Novi Dyah Ayu Putri*, Tomas Iriyanto, Nur Anisa \\ Universitas Negeri Malang, Jl. Semarang No. 5 Malang, Jawa Timur, Indonesia \\ *Penulis korespondensi, Surel: novidyah7@yahoo.com
}

Paper received: 2-1-2021; revised: 23-1-2021; accepted: 30-1-2021

\begin{abstract}
This research aims to (1) implement geometry tunnel circuit games on improving rough motoric skills in children group A at TK Kartika Bojonegoro, (2) improving rough motoric skills in children group A at TK Kartika Bojonegoro through geometry tunnel circuit games. This research used classroom action research with a research model from Kemis and MC Taggart. Each cycle consists of planning, acting and observing, reflecting, and revise plans. This research results showed that through geometry tunnel circuit games, the children group A rough motoric skills at TK Kartika Bojonegoro was increased. This was proved from the pre-action observational result which reached an average 60,83 percent with percentage 38,33 percent. In the cycle I reached an average 67,91 percent with percentage 58,33 percent. While in cycle II reached an average 83,47 percent with percentage 86,11 percent. The children's rough motoric skills in cycle II had increased well and it fulfilled the standard of achievement which was decided from the researcher, that was a minimum of 70 percent.
\end{abstract}

Keywords: : Children Group A; Rough Motoric; Geometry Tunnel Circuit Games

\begin{abstract}
Abstrak
Tujuan penelitian ini adalah (1) menerapkan permainan sirkuit terowongan geometri untuk meningkatkan kemampuan motorik kasar anak kelompok A TK Kartika Bojonegoro (2) meningkatkan kemampuan motorik kasar anak kelompok A TK Kartika Bojonegoro melalui permainan sirkuit terowongan geometri. Rancangan penelitian ini berupa Penelitian Tindakan Kelas (PTK) dengan menggunakan model siklus Kemmis \& Mc Tanggart yang terdiri dari, tahap perencanaan, pelaksanaan dan pengamatan, refleksi, dan perbaikan rencana. Hasil penelitian menunjukkan bahwa melalui penerapan permainan sirkuit terowongan geometri dapat meningkatkan kemampuan motorik kasar anak kelompok A di TK Kartika Bojonegoro. Terbukti pada penelitian pra tindakan mencapai rata-rata 60,83 dengan persentase 38,33 persen, pada siklus I meningkat mencapai rata-rata 67,91 dengan persentase 58,33 persen, sedangkan pada siklus II mencapai rata-rata 83,47 dengan persentase 86,11 persen. Kemampuan motorik kasar anak pada siklus II sudah berkembang sangat baik dan sudah memenuhi standar ketercapaian yang ditetapkan oleh peneliti yaitu minimal 70 persen.
\end{abstract}

Kata kunci: Anak Kelompok A; Motorik Kasar; Permainan Sirkuit Terowongan Geometri

\section{Pendahuluan}

Masa usia dini merupakan masa yang sangat tepat diberikannya bekal untuk masa depan anak yang akan datang. Anak usia dini merupakan anak usia 0-6 tahun yang memiliki pertumbuhan dan perkembangan yang luar biasa. Pertumbuhan dan perkembangan tersebut dapat dikembangkan melalui Pendidikan Anak Usia Dini. Undang-undang nomor 20 tahun 2003 tentang Sistem Pendidikan Nasional pada bab 1 ayat 14 menegaskan bahwa pendidikan anak usia dini adalah suatu upaya pembinaan yang ditujukan kepada anak sejak lahir sampai 
enam tahun yang dilakukan melalui pemberian rangsangan pendidikan dengan tujuan untuk membantu pertumbuhan dan perkembangan jasmani serta rohani agar anak memiliki kesiapan dalam memasuki pendidikan lebih lanjut (Mursid, 2016).

Pendidikan anak usia dini diselenggarakan dengan tujuan untuk mengembangkan seluruh aspek perkembangan pada anak. Seluruh aspek tersebut diantaranya perkembangan motorik kasar. Perkembangan motorik kasar sangat penting distimulasi sejak diri karena secara tidak langsung fisik anak menentukan keterampilannya dalam bergerak. Pengembangan motorik kasar anak dapat dikembangkan melalui aktivitas gerak seperti berjalan, berlari, melompat, dan merangkak. Motorik kasar merupakan gerak fisik yang melibatkan otot-otot besar. Sejalan dengan pendapat Sujiono (2010) yang menyatakan bahwa motorik kasar adalah gerak tubuh yang melibatkan otot-otot besar seperti merayap, berguling, merangkak, duduk, berdiri, berjalan, berlari, melompat, dan berbagai aktivitas menendang, serta aktivitas melempar dan menangkap bola.

Kemampuan motorik kasar anak usia 4-5 tahun memiliki beberapa karakteristik. Berdasarkan Permendikbud No. 137 Tahun 2014 menyebutkan bahwa perkembangan motorik kasar anak pada usia 4-5 tahun diantaranya adalah 1) berjalan pada garis lurus, 2) melompat dengan satu kaki meski belum sempurna, 3) mengayuh dan mengemudikan mainan beroda dengan percaya diri, 4) menaiki tangga, memanjat pohon dan mainan yang bisa dipanjat di taman bermain, 5) melompat setinggi 4 atau 6 inci (12,5 sampai $15 \mathrm{~cm})$, mendarat dengan dua kaki bersama, 6) berlari, memulai, berhenti dan bergerak mengelilingi rintangan dengan mudah, 7) menangkap, melempar, menendang, dan memantulkan bola, 8) melempar bola dengan ayunan atas, dengan jangkauan dan ketepatan yang semakin baik, dan 9) berjongkok untuk memungut benda dari lantai.

Kemampuan motorik kasar anak dapat dikembangkan melalui berbagai cara salah satunya yaitu melalui aktivitas melakukan permainan sirkuit. Andita (2018) berpendapat bahwa perminan sirkuit merupakan jenis permainan yang dilakukan oleh individu atau kelompok untuk mendapatkan suatu perubahan yang positif dan dilakukan secara berurutan dengan melewati setiap posnya dan berkesinambungan. Melewati setiap pos yang tersedia membuat anak harus menggerakkan seluruh anggota tubuh dengan melibatkan otot-otot besar, sehingga pada permainan sirkuit dapat mengembangkan motorik kasar anak.

Pengamatan yang dilakukan oleh peneliti di TK Kartika Bojonegoro pada tanggal 1 Februari 2019 dari 18 anak yang mengikuti pembelajaran motorik kasar pada saat berolahraga dengan gerakan berdiri dengan satu kaki dan mengangkat satu kaki dengan hitungan 1/8 untuk melatih keseimbangan hanya terdapat 5 anak yang memenuhi ketercapaian $\geq 70 \%$, kemudian pada gerakan kedua yaitu push up sebanyak 5 kali untuk mengembangkan unsur kekuatan terdapat 11 anak yang memenuhi ketercapaian, selanjutnya pada gerakan ketiga yaitu melompat ke atas dengan posisi kaki dilebarkan dengan bertepuk 1 kali di atas kepala kemudian setelah bertepuk kaki dirapatkan lagi dan tangan menyentuh paha untuk mengembangkan unsur kelincahan terdapat 11 anak yang mampu memenuhi ketercapaian, kemudian pada gerakan keempat yaitu menirukan gerakan pesawat dengan kaki diangkat ke belakang kemudian secara perlahan diarahkan ke depan untuk mengembangkan unsur koordinasi terdapat 8 anak yang mampu memenuhi ketercapaian, dan pada gerakan terakhir yaitu melompat maju mundur sebanyak 5 kali untuk mengembangan unsur ketepatan tedapat 8 anak yang mampu memenuhi ketercapaian. 
Berdasarkan pengamatan yang sudah dilakukan oleh peneliti dapat dilihat bahwa pada TK Kartika Bojonegoro memiliki permasalahan pada perkembangan motorik kasar anak terutama pada unsur kebugaran jasmani yaitu keseimbangan, ketepatan, kekuatan, kelincahan, dan koordinasi. Permasalahan tersebut dapat dilihat dari jumlah keseluruhan ketercapaian kelas mencapai rata-rata 60,83 dengan persentase 38,89\% dengan kriteria belum berkembang pada aspek motorik kasarnya. Selain itu, pada saat wawancara yang dilakukan oleh peneliti kepada guru sebagai narasumber, guru menjelaskan bahwa di TK Kartika Bojonegoro media pembelajaran yang digunakan untuk meningkatkan kemampuan motorik kasar anak juga minim, beberapa alat permainan di luar kelas untuk mendukung aktivitas motorik kasar anak juga masih terbatas, dan anak cenderung kurang bersemangat dalam melakukan aktivitas motorik kasar seperti senam, karena merasa kesusahan dalam menirukan gerakan yang dicontohkan oleh guru dan karena pembelajaran motorik kasar hanya dilakukan pada saat kegiatan olahraga saja yang dilakukan selama 1 kali dalam seminggu.

Faktor yang menyebabkan terjadinya permasalahan tersebut adalah :1) Anak selama proses pembelajaran di dalam kelas cenderung ditekankan pada aktivitas yang mengembangkan kemampuan fisik motorik halus anak, seperti mewarnai gambar, menebali garis, menggunting dan kegiatan lain yang menggunakan lembar kerja (LK), 2) Kurangnya sarana permainan outdoor yang ada pada sekolah, 3) Kurangnya media pembelajaran yang menunjang aktivitas motorik kasar anak di dalam kelas.

Model pembelajaran yang sering menggunakan lembar kerja (LK) dan menuntut anak untuk mengerjakan dengan duduk di bangku membuat kegiatan bermain anak menjadi berkurang, yang seharusnya pembelajaran dilakukan dengan bermain sambil belajar menjadi tidak ada. Permasalahan tersebut membuat gerak fisik anak menjadi berkurang dan kurang dikembangkan pada saat pembelajaran dilakukan.

Memperhatikan beberapa faktor penyebab permasalahan yang ada pada TK Kartika Bojonegoro, peneliti tertarik untuk memilih melakukan upaya untuk mengembangkan motorik kasar melalui permainan sirkuit terowongan geometri. Permainan ini dipilih oleh peneliti karena berhubungan dengan permasalahan yang ada pada TK Kartika Bojonegoro yaitu untuk mengembangkan motorik kasar anak terutama pada unsur keseimbangan, kekuatan, kelincahan, ketepatan, dan koordinasi. Pada permainan sirkuit terowongan geometri terdapat 5 pos yang harus dilewati anak. 5 pos tersebut diantaranya yaitu berjalan di atas garis zig-zag, merangkak melewati terowongan geometri, merangkak melewati anak tangga, menggelindingkan bola ke dalam 2 gawang, menendang bola ke dalam 2 gawang. Permainan ini dapat meningkatkan kemampuan motorik kasar anak yang didukung oleh pernyataan dari Hadisasmmita (1996) yang menyatakan bahwa latihan sirkuit adalah suatu sistem latihan yang dapat menghasilkan perubahan- perubahan positif pada kemampuan motorik, selain itu juga dapat memperbaiki kesegaran jasmani tubuh, kekuatan otot, daya tahan, kecepatan dan fleksibilitas secara bersamaan.

Berdasarkan hasil penelitian terdahulu oleh Ngestireni pada tahun 2012 yang berjudul "Penerapan Permainan Sirkuit Geometri untuk Meningkatkan Kemampuan Fisik Motorik". Terlihat bahwa kemampuan motorik kasar anak meningkat. Terbukti dari hasil ketercapaian pada siklus I dan siklus II mengalami peningkatan yang signifikan. Melihat pernyataan tersebut, maka untuk membantu mengatasi permasalahan mengenai kemampuan motorik kasar pada anak kelompok A TK Kartika Bojonegoro, peneliti akan melakukan penelitian 
tentang "Peningkatan Kemampuan Motorik Kasar Melalui Permainan Sirkuit Terowongan Geometri pada Anak Kelompok A di TK Kartika Bojonegoro".

\section{Metode}

Penelitian ini menggunakan Penelitian Tindakan Kelas (PTK) yang dilaksanakan selama dua siklus dengan dua kali pertemuan pada setiap siklusnya. Model yang digunakan pada penelitian ini yaitu dari model Kemmis \& MC Taggart (dalam Akbar, 2010). Pada setiap siklus terdiri dari perencanaan, pelaksanaan dan pengamatan, refleksi, dan perbaikan rencana. Jika siklus I dirasa belum dapat mengatasi permasalahan yang ada di sekolah maka akan dilakukan siklus II dengan cara perbaikan dari hasil refleksi pada siklus I.

Penelitian ini dilaksanakan di TK Kartika Bojonegoro yang beralamat di Desa Sendang Rejo Kecamatan Dander Kabupaten Bojonegoro. Penelitian ini dilakukan untuk meningkatkan kemampuan motorik kasar anak melalui permainan terowongan geometri. Aspek yang dinilai dalam penelitian ini adalah ketepatan, keseimbangan, kekuatan, kelincahan dan koordinasi. Peneliti pada penelitian ini bertindak sebagai observer yaitu sebagai perencana kegiatan, pengumpulan data, penganalisa dan pelapor hasil penelitian. Guru pada penelitian ini bertindak sebagai pelaksana kegiatan, teman diskusi, dan merefleksi pada saat peneliti melakukan penelitian.

Teknik analisis data pada penelitian ini adalah kuantitatif dan kualitatif. Analisis pada data kuantitatif diantaranya yaitu observasi aktivitas guru dan observasi kemampuan motorik kasar anak. Sedangkan analisis data kualitatif yaitu catatan lapangan, wawancara, dan dokumentasi kegiatan. Data-data tersebut digunakan untuk mendapatkan informasi mengenai masalah penelitian. Data adalah kumpulan fakta atau angka yang dapat dipercaya sehingga dapat digunakan sebagai dasar untuk menarik suatu kesimpulan. Pada penelitian ini anak dikatakan memenuhi ketercapaian apabila memenuhi persentase $\geq 70 \%$.

\section{Hasil dan Pembahasan}

\subsection{Hasil}

Hasil penelitian yang dilakukan pada anak kelompok A TK Kartika Bojonegoro, pada pra tindakan diketahui bahwa tingkat ketercapaian perkembangan anak belum menunjukkan kemampuan dalam bidang motorik kasarnya dan secara keseluruhan data yang didapat pada pra tindakan yang diperoleh peneliti mencapai rata-rata 60,83 dengan persentase 38,89\% dengan kategori belum berkembang. Dari 18 anak terdapat 11 anak yang tergolong belum berkembang pada kemampuan motorik kasarnya, sedangkan anak lainnya tergolong mampu. Fakta dari data tersebut telah membuktikan bahwa perlu adanya tindakan untuk menyelesaikan permasalahan yang ada di TK Kartika Bojonegoro dalam kemampuan motorik kasar anak terutama pada aspek keseimbangan, kekuatan, kelincahan, ketepatan, dan koordinasi. Pada siklus I pertemuan I setelah menerapkan permainan sirkuit terowongan geometri mendapatkan hasil rata-rata 66,11 dengan persentase $50,00 \%$ dengan kategori belum berkembang. Pada pertemuan ini dari 18 anak hanya terdapat 9 anak yang memenuhi ketercapaian, 9 anak yang lainnya belum memenuhi ketercapaian. Sedangkan pada siklus I Pertemuan II terjadi peningkatan. Dari 18 anak menjadi 12 anak yang memenuhi ketercapaian dengan mendapat rata-rata 69,72 dan persentase $66,67 \%$. Hasil akumulasi siklus I pertemuan I dan pertemuan II diperoleh data klasikal rata-rata 67,91 dengan persentase 58,33\% dengan kategori mulai berkembang. Pada siklus I mengalami peningkatan dari penelitian pra tindakan 
yaitu dengan rata-rata meningkat 7,06 dan persentase meningkat $19,44 \%$. Pada pra tindakan dengan siklus I memang meningkat, namun belum memenuhi ketercapaian yang peneliti harapkan yaitu minimal 70\%. Maka dari itu, perlu adanya perbaikan pada siklus II untuk meningkatkan kemampuan motorik kasar anak agar lebih berkembang secara optimal.

Pada siklus II pertemuan I diperoleh data bahwa dari 18 anak 14 anak mampu memenuhi ketercapaian dengan rata-rata mencapai 77,78 dengan persentase $77,78 \%$ dengan kategori berkembang sesuai harapan dan 4 anak masih belum memenuhi ketercapaian. Sedangkan pada siklus II pertemuan II hasil yang didapat pada pertemuan ini mengalami peningkatan dari 18 anak 17 anak mampu memenuhi ketercapaian dengan rata-rata 89,17 dengan persentase 94,44\%. Pada pertemuan ini hasil persentase masuk dalam kategori berkembang sangat baik.

Hasil akumulasi siklus II pertemuan I dan pertemuan II diperoleh data klasikal rata-rata mencapai 83,47 dengan persentase 86,11 dengan kategori berkembang sangat baik. Jika dilihat secara keseluruhan dari siklus I ke siklus II mengalami peningkatan yaitu rata-rata mencapai 15,56 dengan peningkatan persentase 27,78\%. Hasil pada siklus II sudah memenuhi standar ketercapaian yang peneliti tetapkan yaitu minimal adalah 70\%. Maka dari itu, penelitian ini dianggap berhasil dan berhenti sampai siklus II. Hasil penelitian menunjukkan bahwa melalui permainan sirkuit terowongan geometri dapat meningkatkan kemampuan motorik kasar anak di TK Kartika Bojonegoro. Peningkatan yang terjadi pada pra tindakan, siklus I, dan siklus II dapat dilihat pada diagram berikut ini.

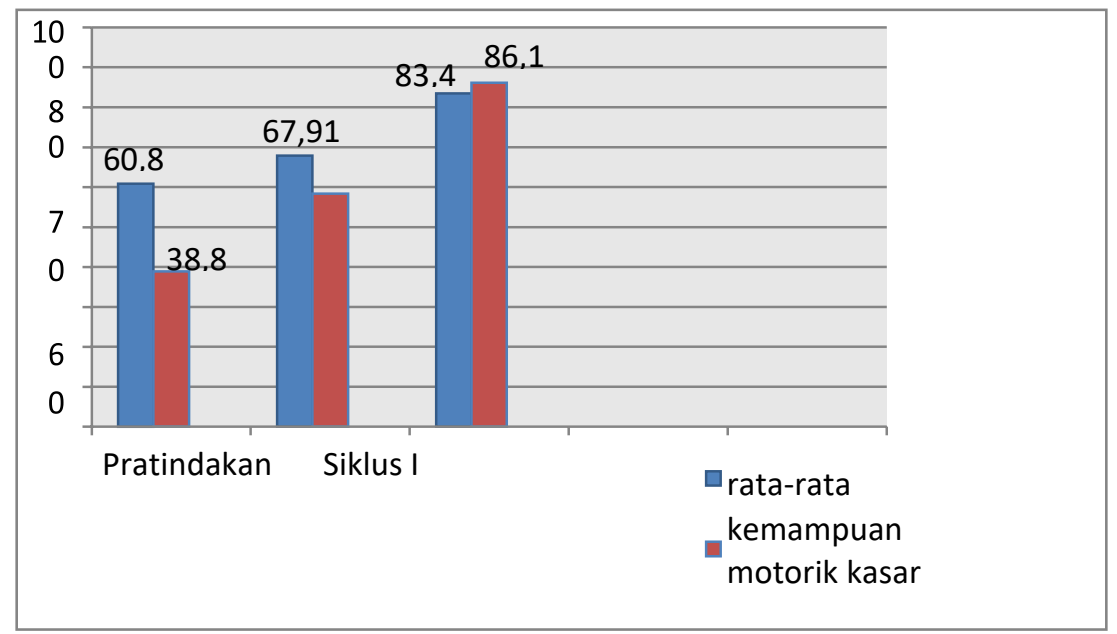

\section{Gambar 1. Diagram Hasil Peningkatan Kemampuan Motorik Kasar Anak melalui Permainan Sirkuit Terowongan Geometri dari Penelitian Pra Tindakan, Siklus I dan Siklus II}

Pada gambar diagram tersebut dapat diketahui bahwa kemampuan motorik kasar anak pada penelitian pra tindakan mencapai rata-rata 60,83 dengan persentase 38,89\% dengan kategori belum berkembang, pada siklus I mencapai rata-rata 67,91 dengan persentase $58,33 \%$ dengan kategori mulai berkembang, siklus II mencapai rata-rata 83,47 dengan persentase $86,11 \%$ berkembang sangat baik. Peningkatan kemampuan motorik kasar anak dari pratindakan ke siklus I meningkat mencapai rata-rata 7,06 dengan persentase 19,44\%, dan siklus I ke siklus II meningkat rata-rata 15,56 dengan persentase 27,78 \%. 


\subsection{Pembahasan}

Paragraf berisi uraian sub judul 2.

\subsubsection{Penerapan Permainan Sirkuit Terowongan Geometri untuk Meningkatkan Kemampuan Motorik Kasar Anak pada Kelompok A di TK Kartika Bojonegoro}

Permainan sirkuit terowongan geometri adalah salah satu kegiatan yang dipilih peneliti dalam upaya untuk meningkatkan kemampuan motorik kasar anak. Andita (2018) berpendapat bahwa permainan sirkuit merupakan jenis permainan yang dilakukan individu atau kelompok untuk mendapatkan suatu perubahan positif dan dilakukan secara berurutan dengan melewati setiap posnya dan berkesinambungan. Perubahan positif tersebut salah satunya adalah motorik kasar anak karena dengan melewati setiap pos yang ada pada permainan sirkuit, otot-otot besar dalam diri anak akan bergerak sehingga motorik kasar anak dapat berkembang. Sejalan dengan pendapat dari Hadisasmita (1996) yang menyatakan bahwa latihan sirkuit adalah suatu sistem latihan yang dapat menghasilkan perubahanperubahan positif pada kemampuan motorik, selain itu juga dapat memperbaiki kesegaran jasmani tubuh, kekuatan otot, daya tahan, kecepatan, dan fleksibilitas secara bersamaan. Maka dari itu peneliti memilih permainan sirkuit terowongan geometri untuk mengembangkan kemampuan motorik kasar anak Kelompok A TK Kartika Bojonegoro.

Permainan sirkuit terowongan geometri pada penerapannya memiliki aturan permainan. Aturan permainan dalam penerapan permainan sirkuit terowongan geometri yaitu anak harus melewati dengan urut pos ke 1 sampai dengan pos ke 5 dengan cara pos 1 anak harus berjalan di atas garis tanpa melewati garis untuk mengembangkan aspek keseimbangan, pada pos ke 2 anak merangkak melewati 4 terowongan geometri untuk mengembangkan kekuatan anak, pada pos ke 3 anak merangkak zig-zag melewati 5 anak tangga untuk mengembangkan kelincahan anak, dan pos ke 4 yaitu menggelinding bola ke dalam 2 gawang dengan jarak 3 meter untuk mengembangkan ketepatan, dan pos ke 5 atau pos terakhir menendang bola ke dalam 2 gawang dengan jarak 3 meter untuk mengembangkan koordinasi anak. Pada saat siklus I masih terdapat banyak anak yang belum paham dengan aturan permainannya dan terdapat beberapa gejala yang membuat motorik kasar anak belum meningkat sesuai dengan kriteria ketercapaian. Gejala tersebut diantaranya yaitu permainan yang dimainkan di dalam kelas terlalu sempit sehingga anak tidak dapat bergerak bebas, gawang yang digunakan pada pos ke 4 dan ke 5 dijadikan satu sehingga membuat anak bingung dalam memainkannya dan yang terakhir yaitu media permainannya kurang berwarna. Melihat hasil refleksi tersebut peneliti melakukan perbaikan pada siklus II yang dilakukan 2 kali pertemuan pada setiap siklusnya. Perbaikan tersebut membuat kemampuan motorik kasar anak mengalami peningkatan. Berikut hasil dari penerapan permainan sirkuit terowongan geometri.

Pada tahap awal masing-masing siklus dimulai dari baris berbaris di halaman sekolah kemudian dilanjutkan bernyanyi sop yang ada pada TK Kartika dan menyebutkan asmaul husna. Setelah itu guru mengajak anak untuk masuk ke dalam kelas melakukan do'a sebelum pembelajaran, memberi salam, presensi, bertanya hari, tanggal, bulan dan tahun. Kemudian guru memberikan apersepsi kepada anak mengenai tema yang bersangkutan pada hari ini. Guru menjelaskan kegiatan yang akan dilakukan oleh anak pada hari itu. 
Pada saat pelaksanaan kegiatan, guru menyiapkan permainan sirkuit terowongan geometri. Setelah menyiapkan permainan guru melakukan tanya jawab terlebih dahulu dengan anak mengenai tema pada hari ini dengan menyamakan bentuk geometri pada permainan sirkuit terowongan geometri dengan tujuan untuk mengenalkan kepada anak mengenai bentuk geometri seperti lingkaran, persegi dan segitiga. Guru kemudian menjelaskan langkahlangkah permainan sirkuit terowongan geometri. Setelah menjelaskan anak-anak diminta untuk bermain sesuai urutan absen dan teman yang belum waktunya bermain untuk menyemangati teman yang sedang melakukan permainan. Pada saat pelaksanaan siklus I anakanak masih terlihat belum sepenuhnya memahami aturan permainan dan cara melakukan permainannya. Hal ini dikarenakan anak-anak kurang memperhatikan penjelasan dari guru dan sudah terfokus ingin langsung melakukan permainan dan kegiatan yang dilakukan di dalam kelas membuat anak sulit untuk bergerak bebas karena ruangan yang kurang leluasa untuk dilakukan permainan sehingga tingkat ketercapaian untuk mengembangkan motorik kasar anak belum terpenuhi. Setelah mendapatkan data dari siklus I peneliti dan guru melakukan rencana perbaikan pada aktivitas pembelajaran yang dilakukan melalui permainan sirkuit terowongan geometri. Pada siklus II pelaksanaan pembelajaran sama dengan siklus I hanya saja pada siklus II permainan dilakukan di luar kelas dengan permainan yang sudah dicat warna warni agar lebih menarik anak dan guru disini mengajak anak untuk melakukan perjanjian awal untuk mendengarkan guru pada saat menjelaskan langkah-langkah atau aturan permainan dan mengajak anak berbaris untuk melihat permainan agar mereka lebih fokus pada saat guru mencontohkan cara melakukan permainan. Selain itu, motivasi selalu diberikan oleh guru kepada anak-anak agar selalu bersemangat dan berkonsentrasi dalam melewati setiap pos pada permainan sirkuit terowongan geometri.

Berdasarkan fakta dalam pelaksanaan permainan sirkuit terowongan geometri tersebut dapat disimpulkan bahwa hasil yang diperoleh pada siklus II setelah diadakannya perbaikan mengalami peningkatan dibandingkan dengan pembelajaran sebelumnya yang dilakukan pada siklus I dalam hal mengembangkan kemampuan motorik kasar anak kelompok A di TK Kartika Bojonegoro.

\subsubsection{Peningkatan Kemampuan Motorik Kasar Anak melalui permainan Sirkuit Terowongan Geometri}

Permainan sirkuit terowongan geometri dapat meningkatkan motorik kasar anak karena melalui kegiatan ini anak dilatih untuk menggerakan otot-otot besar yang ada di dalam tubuh pada saat melewati setiap pos yang ada pada permainan. Terbukti dari hasil penelitian yang telah dilakukan, pada pra tindakan kemampuan motorik kasar anak mencapai rata-rata 60,83 dengan persentase 38,89\%, pada siklus I pertemuan 1 kemampuan motorik kasar anak mencapai rata-rata 66,11 dengan persentase $50 \%$, pada siklus I pertemuan 2 kemampuan motorik kasar anak mencapai rata-rata 69,72 dengan persentase 66,67\%. Dari perolehan data tersebut maka rata-rata kelas pada siklus I sebesar 68,19 dengan persentase 58,33\%. Dilihat dari hasil siklus I bahwa motorik kasar anak belum bekermbang dan belum mencapai minimal 70\% maka penelitian akan dilanjutkan ke siklus II.

Pada penelitian siklus II pertemuan 1 diperoleh rata-rata 77,78 dengan persentase $77,78 \%$ dengan kategori berkembang sesuai harapan, pada pertemuan ke 2 diperoleh rata-rata 89,17 dengan persentase 94,44\% dengan kategori berkembang sangat baik. Hasil data yang sudah diperoleh dari siklus II pertemuan I dan 2 dapat dihitung rata-rata kelas yaiu sebesar 
83,47 dengan persentase $86,11 \%$. Maka dapat dilihat terdapat peningkatan kemampuan motorik kasar anak dari hasil penelitian siklus I mencapai rata-rata 68,19 dengan persentase $58,33 \%$ dan pada penelitian siklus II mencapai rata-rata 83,47 dengan persentase $86,11 \%$. Karena kemampuan motorik kasar anak melalui permainan sirkuit terowongan geometri sudah melebihi ketercapaian yang sudah peneliti tetapkan yaitu sebesar $70 \%$, maka peneliti mengakhiri penelitian pada siklus II

Berdasarkan uraian tersebut, dapat disimpulkan bahwa melalui permainan sirkuit terowongan geometri maka kemampuan motorik kasar anak kelompok A di TK Kartika Bojonegoro pada siklus I ke siklus II meningkat rata-rata mencapai 15,56 dan untuk persentase meningkat $27,78 \%$ dengan pencapaian nilai rata-rata 83,47 dengan persentase $86,11 \%$. Hal ini sejalan dengan pendapat dari Hadisasmita (1996:110), latihan sirkuit merupakan suatu bentuk latihan yang dapat menghasilkan perubahan-perubahan positif pada kemampuan motorik, selain itu juga dapat memperbaiki secara bersamaan kesegaran jasmani dari dalam tubuh.

\section{Simpulan}

Berdasarkan hasil penelitian dan pembahasan mengenai peningkatan kemampuan motorik kasar anak kelompok A di TK Kartika Bojonegoro pada bab sebelumnya, dapat disimpulkan bahwa penerapan kegiatan pembelajaran menggunakan permainan sirkuit terowongan geometri dilaksanakan menjadi 2 siklus, dengan masing-masing siklus dua kali pertemuan. Penerapan permainan tersebut dimulai dengan kegiatan awal, inti, istirahat, dan akhir. Berdasarkan fakta dalam pelaksanaan permainan sirkuit terowongan geometri diketahui hasil bahwa pada siklus II mengalami peningkatan yang sangat baik dari pembelajaran pada siklus sebelumnya dalam hal mengembangkan kemampuan motorik kasar anak kelompok A di TK Kartika Bojonegoro terutama pada unsur keseimbangan, kekuatan, kelincahan, ketepatan, dan koordinasi.

Penerapan permainan sirkuit terowongan geometri dapat meningkatkan kemampuan motorik kasar anak kelompok A di TK kartika Bojonegoro. Hal ini terbukti dari hasil penelitian siklus I dan siklus II yang mengalami perkembangan yang signifikan. Terlihat dari hasil keseluruhan siklus I yaitu mencapai rata-rata I rata-rata skor mencapai 67,81 dengan persentase $58,33 \%$ dengan kategori mulai berkembang dan pada siklus II rata-rata skor mencapai $83,47 \%$ dengan persentase $86,11 \%$ dengan kategori berkembangan sangat baik dan sudah memenuhi tingkat ketercapaian yang diharapkan oleh peneliti.

Berdasarkan penelitian yang telah dilaksanakan di TK Kartika Bojonegoro, terdapat beberapa saran untuk kedepannya, yaitu yang ke (1) bagi lembaga sekolah Untuk kedepannya guna menunjang keberhasilan dalam meningkatkan aspek kemampuan anak terutama motorik kaasar hendaknya menggunakan media yang lebih inovatif, (2) bagi guru diharapkan Untuk mengembangkan kemampuan motorik kasar anak hendaknya guru menggunakan media yang kreatif dengan memanfaatkan media yang ada di sekitar lingkungan, salah satunya dapat menerapkan permainan sirkuit terowongan geometri yang lebih bervariasi lagi, (3) bagi orangtua diharapkan dapat membantu guru dalam menstimulasi motorik kasar anak dirumah. Misalkan dengan memberikan gizi yang seimbang untuk pertumbuhan dan perkembangan yang optimal, (4) bagi peneliti lain diharapkan dapat mengembangkan penelitian ini menjadi penelitian yang lebih kreatif dan memiliki manfaat untuk mengembangkan aspek-aspek perkembangan anak usia dini. 
Jurnal Pembelajaran, Bimbingan, dan Pengelolaan Pendidikan, 1(1), 2021, 54-62

\section{Daftar Rujukan}

Akbar, S. (2010). Penelitian Tindakan Kelas: Filosofi, Metodologi \& Implementasi. Yogyakarta: Cipta Media Aksara.

Andita, R. W. (2018). Peningkatan Kemampuan Motorik Kasar Anak Melalui Bermain Treasure Circuit untuk Kelompok B TK Margi Asih 2 Kota Batu. Malang: Universitas Negeri Malang.

Hadisasmita, Y \& Syarifuddin A. (1996). Ilmu Kepelatihan Dasar. Jakarta: Dapartemen Kependidikan dan Kebudayaan.

Mursid. (2016). Pengembangan Pembelajaran Paud. Bandung: PT Remaja Rosdakarya.

Sujiono, Y. N. (2010). Bermain Kreatif Berbasis Kecerdasan Jamak. PT Indeks.

Undang-undang Permendikbud Tahun 2014. (2014). Jakarta: Depdiknas. 